\title{
Probable aestivation burrows from the Eocene/Oligocene transition in south-eastern France and their palaeoenvironmental implications
}

\author{
Christian Gaillard, Davide Olivero ${ }^{*}$, Marie Chebance
}

Laboratoire de Géologie de Lyon, Terre, Planètes et Environnement, CNRS UMR 5276, Université Claude Bernard Lyon1, 2 rue Raphaël Dubois, F-69622 Villeurbanne Cedex, France

\begin{abstract}
Enigmatic biogenic structures are reported from the Palaeogene of south-eastern France in the Castellane-Blieux area (Alpes de Haute-Provence French department). They occur at the Eocene/Oligocene transition at the top of the Marnes Bleues Formation, which corresponds to a clearly defined regressive sequence, where thick marls are overlain by lacustrine limestones or sandstones. The marls have abundant shallow marine fauna and the upper part of the Formation corresponds to a rapid transition to non-marine deposits. The studied structures exhibit three main morphologies: vertical shafts, furrows, and tunnels. They can also form dense clusters and crosscut marginal marine crustacean burrows such as Psilonichnus. By comparison with modern and fossil examples, these trace fossils are interpreted as probably aestivation burrows. The possible trace-makers could be lungfish (in particular for the common vertical burrows) or amphibians (for the furrows and tunnels). The occurrence of these different aestivation burrows defines the border of a basin and probably indicates increasing droughts on the coastal plain. This could reflect the well-known development of arid conditions in south-eastern France at the beginning of the Oligocene.
\end{abstract}

\footnotetext{
* Corresponding author. E-mail address: Davide.olivero@univ-lyon1.fr Telephone: (33) 472431322
} 
Keywords: Aestivation burrows; Lungfish; Amphibian; Paleoclimatology; Eocene/Oligocene; south-eastern France

\section{Introduction}

Uncommon large burrows characterize marginal marine to terrestrial deposits occurring in south-eastern France at the transition between Eocene and Oligocene. They have been only briefly described in the French literature (Gitton, 1978), but their origin and the identity of the tracemakers have never been determined. They are associated with more common crustacean burrows (Thalassinoides and Psilonichnus). These trace fossils occur in sediments deposited at the end of a regression event recorded in the French Subalpine Basin. They are also possibly related to the climatic evolution occurring during this period, which is indicated by a global cooling and drying. Because of their potential palaeogeographical and palaeoclimatical significance, these trace fossils could be good environmental indicators in this succession. The aim of this work is to describe these burrows, to discuss the possible identity of the trace-makers, and to evaluate their palaeoenvironmental significance.

\section{Geological setting}

\subsection{Paleogeography}

During the Palaeogene time, the paleogeography of Western Europe was characterized by a complex patchwork of different environments (Meulenkamp et al., 2000). The south-eastern France area, which belonged to the old Tethys domain, today is characterized by a complex geology resulting from tectonic evolution of the Alps. In front of the first newly-formed mountain belt, a curved foreland basin occurred. The French western and southern limits of this basin are well known (Bodelle, 1971; Cavelier et al., 1984). This basin was fully marine in the late Eocene 
(Priabonian). During the early Oligocene, an important regression occurred and a sharp transition occurred from eastern deep marine deposits to western shallow marine and lacustrine deposits. Such a paleogeography is well documented from the late Rupelian (early Oligocene, 32-29 Ma) (Fig. 1). The study area (Fig. 2) is located at the south-western termination of this basin and the studied interval is slightly older (mainly the late Eocene).

\subsection{Stratigraphy}

The stratigraphy of the study area (Fig. 3) records the paleogeographic transition between the Eocene and Oligocene (Boussac, 1912; Bodelle, 1971; Gitton, 1978; Cavelier et al., 1984). The deposits are successively (Fig. 3A): 1, fully marine conglomerates, sandstones, and limestones of the Calcaires Nummulithiques Formation; 2, shallow marine to brackish fossiliferous marls of the Marnes Bleues Formation; and 3, lacustrine limestones or continental sandstones. In the more distal parts of the basin (Fig. 3B), near Barrême or Annot, the Marnes Bleues Formation is more than $250 \mathrm{~m}$ thick and covered by the sandstones of the Grès d'Annot or the Grès de Senez Formations. In the more proximal parts of the same basin, near Castellane or Blieux, the Marnes Bleues Formation is nearly $100 \mathrm{~m}$ thick and covered by the lacustrine limestones of the Calcaire Lacustre de Taulanne Formation. Near Castellane (Figs. 2, 3B), the Calcaires Nummulitiques Formation and the Marnes Bleues Formation are assigned to the Priabonian. The Eocene/Oligocene boundary is probably situated at the top of the Marnes Bleues Formation (Gitton, 1978), in the so-called "Couches bistres" interval (Fig. 3), whereas the Calcaire Lacustre de Taulanne Formation is related to the Sannoisian-early Stampian (Gitton, 1978). Here, the studied trace fossils, which were previously named "pivots" by Gitton (1978), occur at the Eocene/Oligocene transition at the top of the Marnes Bleues Formation, mainly in the "Couches bistres" (Figs. 4, 5). The "Couches bistres" interval is visible in the more south-western deposits of the basin, between Blieux and Castellane (Fig. 3). The best place to see the trace fossils described 
here is the area of Castellane and the best section is the Brayal section (Figs. 2, 3, 4, 5). This section is also known under the name "Vit de Castellane" and has been studied for a long time (d'Orbigny, 1850), but without any interest for its ichnologic aspect. Other good sections are located near the Blieux village (Ravin de la Bourbonne and Barre de l'Echelette) and near Annot (Braux locality) (Fig. 2).

\subsection{Depositional environment}

In the Brayal section (Figs. 4, 5), the upper part of the Marnes Bleues Formation (with the "Couches bistres") and the Calcaire Lacustre de Taulanne Formation are well exposed. The Marnes Bleues Formation, which is 109 m thick, consists mostly of a fossiliferous blue-gray calcareous clays $\left(50 \% \mathrm{CaCO}_{3}\right)$ with some sandstone beds. Clays are mainly montmorillonite $(60 \%)$ with illite (15\%) and kaolinite (15\%). Quartz, mica and heavy minerals are also present (Bodelle, 1971). The macro-fauna is diverse (Boussac, 1911; Gitton, 1978) and consists of bivalves (Arctica plana, Chlamys biarritzensis, Cordiopsis incrassata, Glossus subtransversus, Lentipecten corneus, Panopea allonsensis, Pycnodonte gigantean, Venericardia astieri and numerous other taxa), gastropods (Athleta, Calyptraea, Tibia, Turitella), scaphopods (Dentalium castellanensis), brachiopods (Terebratulina), bryozoans (Cellepora), echinoids (Echinolampas, Schizaster), solitary corals, crustaceans (Coeloma vigil), and fishes (mainly represented by shark teeth). Some plant remains also occur (wood fragments). These fossils clearly indicate a shallow marine environment. At the top of these marls some levels with diagenetic calcareous nodules occur (level 14d, Fig. 4).

The "Couches bistres" interval is a yellowish to reddish silty-argillaceous deposit including fine-grained sandstone beds. This deposit probably indicates shallower environments with occasional subaerial exposure. Quartz is more abundant and dolomite and chlorite occur in small amounts locally (Bodelle, 1971). Planktonic foraminiferans (Globigerina), which occurred in the 
subjacent blue marls, are now absent. The occurrence of miliolids and naticid gastropods indicates the last marine conditions. Brackish conditions are indicated by the occurrence of some abundant ostracods such as Cytheridea (Bodelle, 1971; Gitton, 1978). Some of the studied trace fossils occur in the uppermost part of the blue marls, but they only occur in the "Couches bistres" interval. Clearly, the "Couches bistres" mainly records brackish to non-marine deposits preceding the important emersion that characterizes the beginning of the Oligocene. The corresponding palaeoenvironment was probably a coastal plain still episodically flooded by the very shallow sea. In level no 15 of the "Couches bistres" interval (Figs. 4, 5), some of the studied burrows cross a well exposed whitish level made of flattened rounded nodules 100 to $150 \mathrm{~mm}$ in diameter (Fig. 6). These nodules are calcareous, very fine-grained, and possibly of pedogenetic origin. Similar pedogenetic features have been described in similar environments, for example in the Upper Permian to Lower Triassic deposits of the Karoo Basin (South Africa), where palaeosols are characterized by carbonate nodules associated with possible decapod burrows (Gastaldo and Rolerson, 2008).

Above this interval, the Calcaire Lacustre de Taulanne Formation begins with calcareous conglomerates $\left(80 \% \mathrm{CaCO}_{3}\right)$. The lacustrine environment is demonstrated by gastropods such as Nystia. The succession of deposits in the Brayal section clearly indicates a gradual transition from shallow marine environments to continental environments.

In the other well exposed sections of the same area, for example the La Bourbonne, the Barre de l'Echelette and the Braux sections, the "Couches bistres" interval is absent but the studied trace fossils (clearly visible in the level 15 of Brayal section) are observed in calcareous beds from the uppermost part of the Marnes Bleues Formation (Figs. 3B, 7).

\section{Description of trace fossils}


Even if the studied structures may be considered as enigmatic, with respect to their tracemakers, their biogenic origin does not seem doubtful and all are described as trace fossils. Some characteristic specimens illustrated in this paper are housed in the Collections de Géologie de l’Université de Lyon (FSL 157186-157196).

\subsection{Vertical burrows}

These are the most common biogenic structures occurring in the studied deposits. About fifty specimens have been observed and studied in the field. They are prominent hypichnia clearly visible at the base of some silty limestone beds occurring in the "Couches bistres" interval (Brayal section) or in some of the calcareous beds occurring at the top of the Marnes Bleues Formation (La Bourbonne, Barre de l'Echelette and Braux sections). They correspond to the "pivots" described by Gitton (1978) and are named "vertical burrows" in this paper. They are either isolated (Fig. 8) or occurring in dense clusters including 5 to 7 specimens (Fig. 9). Morphologically, they correspond to vertical burrows with a circular widening-up opening and a cylindrical shaft, slightly tapering downward. The bottom is rounded. The average diameter is $100 \mathrm{~mm}$ and the maximum diameter is $170 \mathrm{~mm}$. The average length is $450 \mathrm{~mm}$ and the maximum length is $900 \mathrm{~mm}$. One prominent longitudinal ridge commonly occurs along the vertical burrow (Fig. 10). This longitudinal ridge is in average 20 to $40 \mathrm{~mm}$ long and 10 to $20 \mathrm{~mm}$ high. The filling is passive and often made of finegrained material (sandstone) with a very regular thinning upward cup-shaped lamination (Fig. 8A). It may also contain different kinds of bioclasts, mainly fragmented bivalve shells (Fig. 8C). Scratch marks are absent but the external surface of the structure frequently shows a more or less visible pustular relief (Figs. 10B, 11).

\subsection{Furrow fills}


These biogenic structures are less common, occurring in association with the vertical shafts. About ten specimens have been observed in the Brayal section. Furrow fills are large hypichnial structures consisting of large grooves 100 to $330 \mathrm{~mm}$ wide and 130 to $600 \mathrm{~mm}$ long. Their vertical section is nearly triangular with a rounded bottom (Fig. 12). They penetrate vertically in the enclosing sediment (depth up to $400 \mathrm{~mm}$ ). As with the vertical shafts, the filling is made of finegrained sandstone with a very regular thinning upward cup-shaped lamination. Some specimens exhibit an external ornamentation made of several structures resembling scratch marks about 20 mm wide and $35 \mathrm{~mm}$ long (Fig. 13). These structures are made of sets of parallel ridges (five at maximum), parallel or oblique to the longitudinal axis of the furrow fill. Individual ridges are 2 to $3 \mathrm{~mm}$ wide and 20 to $30 \mathrm{~mm}$ long.

\subsection{Tunnels}

Tunnel-shaped burrows have been observed only rarely in the Brayal section. They are large, simple exichnial, horizontal galleries visible only a few centimetres under their related bed (Figs. 12, 14). Their cross section is nearly circular (diameter 100 to $230 \mathrm{~mm}$ ), tapering slightly downward. They look like furrow fills but without visible connection with the overlying bed. Their mean length could not be established. Special ornamentation has not been observed in the studied specimens. In the Brayal section, tunnels commonly occur along with the vertical shafts and furrows at the same levels (Fig. 12) where they show exactly the same laminated passive filling. As shown at the base of the bed no. 15 of the Brayal section, all the forms (vertical shafts, furrows and tunnels) may be associated in clusters (Figs. 4, 5).

\subsection{Associated trace fossils}

Different, more abundant burrows occur with the above described traces fossils and are commonly cross-cut by them. They are Thalassinoides and Psilonichnus. These two well-known 
ichnogenera have been observed in all the studied sections. Psilonichnus, which is characterized by well-preserved vertical Y burrows, is the most visible (Fig. 15A, B). Its diameter is 20 to $45 \mathrm{~mm}$ and vertical length is up to $400 \mathrm{~mm}$. Thalassinoides forms some discrete horizontal tunnels (Fig. 12A) with characteristic $\mathrm{Y}$ branching (Fig. 15C). Its diameter is 30 to $50 \mathrm{~mm}$. Various smaller burrows (diameter 10 to $20 \mathrm{~mm}$ ) also occur and are more difficult to characterize. All these burrows have a massive filling that contrasts with the generally laminated filling of the cross-cut trace fossils. Some small simple burrows (diameter 5 to $10 \mathrm{~mm}$ ) clearly cross the shafts, furrows, and tunnels previously described (Figs. 11C, 14). They are commonly preserved as pustulae at the exterior of the cross-cut burrows (Figs. 10B, 11B). Crossings may be transverse, longitudinal or oblique with respect to bedding.

\section{Interpretation}

Because of their common association (clusters), their rare but limited occurrence (only in some specific levels) and their similar preservation (same filling and position relative to bedding), the above-described trace fossils were made at the same time and probably have a similar origin. Physical or vegetal (root traces) origins can be rejected, but different animal producers may be possible.

\subsection{Crustacean burrow hypothesis}

A burrow interpretation is plausible because the morphologies of the studied structures are consistent with burrow shapes and because an open cavity with a passive filling is a common feature of endobenthic tunnels. Invertebrates are possible trace-makers and the more probable ones are crustaceans, because other true crustacean burrows (Thalassinoides, Psilonichnus) are common in the same deposits. Fossil crabs, such as Coeloma vigil, also occur in the enclosing sediments (Gitton, 1978). Moreover, some modern crustacean burrows are morphologically similar to the 
vertical shafts. For example, Farrow (1971, fig. 10) illustrates burrows of the mole crab Albunea, which are simple vertical shafts $600 \mathrm{~mm}$ long. But they are more tapered and they never have the characteristic longitudinal ridge. There is a closer resemblance to freshwater crayfish burrows (Hasiotis and Mitchell, 1993). For example, crayfish burrows described by Smith et al. (2008) in the Palaeogene Willwood Formation are vertical cylindrical burrows, 15 to $50 \mathrm{~mm}$ in diameter, up to $400 \mathrm{~mm}$ long, with a rounded to bulbous deep termination. They are often locally numerous and form "prismatic soil structures" in ancient palaeosols. Abundant crayfish burrows have also been reported in the Upper Triassic (Hasiotis and Dubiel, 1994), Upper Jurassic (Hasiotis et al., 1998) and Palaeocene palaeosols (Hasiotis and Horney, 2000; Bedatou et al., 2008). Their rather similar morphology and their frequent association with pedogenetic features such as carbonate nodules (Smith et al., 2008) support this hypothesis. However, for the Brayal ichnoassemblage, only the vertical shafts could be explained by the crustacean hypothesis.

\subsection{Vertebrate burrows hypothesis}

Vertebrate burrows are rarely reported but they are structurally varied and occur in different environments (Voorhies, 1975; Miller et al., 2001; Hasiotis et al., 2004; Hembree et al., 2004). Among them, some are made by vertebrates able to burrow in aquatic environments.

\subsubsection{Marine fish burrows}

In some cases, excavations made by fishes may lead to interesting trace fossils, as with ray feeding structures (Howard et al., 1977; Martinell et al., 2001). These traces correspond to wellknown shallow structures such as Piscichnus waitemata (Gregory, 1991; Kotake, 2007) having no clear similarities to the studied traces. Furrows are the most similar to those examples, but their typical scratch marks (Fig. 13) cannot be explained by a fish activity. Numerous fishes have also a true fossorial mode of life and resulting burrows show different morphologies (Atkinson and 
Taylor, 1991). The ichnogenus Communichnus was proposed by Snedden (1991) for similar Cretaceous structures occurring along an erosional surface separating ebb-tidal delta sandstones and shelf shales. Snedden (1991) interpreted the probable trace-maker as a tilefish. In fact, similar burrows are made by the modern tilefish Lopholatilus chamaeleonticeps in muddy sediment (Able et al., 1982, 1993; Grimes et al., 1986). L. chamaeleonticeps is a large fish (length up to $125 \mathrm{~cm}$; weight up to $30 \mathrm{~kg}$ ) living in Western Atlantic (Canada to Florida), where it burrows into mud or sand bottoms. The burrow is a funnel-shape hole that ranges up to $1.5 \mathrm{~m}$ in diameter at the sediment surface and narrows to a vertical shaft at the bottom. The vertical shaft is up to $1 \mathrm{~m}$ long. Burrows are distributed in clusters or as individuals. They are observed at the seafloor, filled in with sediment to varying degrees. But these burrows occur on the continental slope, for example off Georgia from 80 to 300 m water depth (Grimes et al., 1986). This does not compare favourably with the palaeoenvironment studied here. Some fishes burrow in shallow marine environments. For example, the sand lance Ammodytes americanus is an active burrower preferring only sandy substrates. Opistognathus aurifrons is also a burrower living in coral reef environments of Western Atlantic (Florida, Bahamas, Barbados), but its burrow with a large deep chamber and accumulation of stones is different (Colin, 1973). For these reasons, the studied trace fossils are probably not made by true marine fishes, similar to the ones living today.

\subsubsection{Lungfish aestivation burrows}

Lungfish commonly dig protective burrows to survive during dry seasons. They are known for $400 \mathrm{Ma}$ and already thrived during the Devonian. Today there are only a few taxa of dipneusts living in South America, Africa, and Australia, and their burrows are well known (Johnels and Svennson, 1954; Blanc et al., 1956; Arambourg and Guibé, 1958). These burrows are commonly found in the Carboniferous, Permian, Triassic, and Cretaceous continental deposits of an arid climate (Romer and Olson, 1954; Carroll, 1965; Carlson, 1968; Olson and Bolles, 1975; Berman, 
1976; Dubiel et al., 1987; Hasiotis et al., 1993; Surlyk et al., 2008). These burrows are able to provide very good proxies for climatic reconstructions, but they are rarely reported from the Cainozoic geological periods.

Some lungfish, such as the modern lepidosirenids (Lepidosiren from South America and Protopterus from Africa), burrow in order to escape desiccation during dry season's aestivation (Arambourg and Guibé, 1958). Burrows of Protopterus annectens are the best known (Johnels and Svennson, 1954; Blanc et al., 1956). In spite of experimental studies, the burrowing activity of this lungfish is not so clear: it may form a simple vertical burrow (Johnels and Svennson, 1954) or a vertical U-shaped burrow with one opening used only for burrowing and then rapidly left (Blanc et al., 1956). In both cases, the lungfish shows a final vertical position in a simple permanent burrow. The oldest burrows of lungfish origin have been described from the Devonian deposits (Woodrow and Fletcher, 1969), but without any skeletal remains inside. Mainly Permian and possibly Triassic deposits have yielded more convincing aestivation burrows of lungfish (Romer and Olson, 1954; Carroll, 1965; Carlson, 1968; Olson and Bolles, 1975; Berman, 1976; Dubiel et al., 1987; Hasiotis et al., 1993). As to their morphology, they are not always easily differentiated from crustacean burrows, for example crayfish burrows that occur in similar environments (Hasiotis et al., 1993). Because of the lack of definitive evidence, some supposed lungfish burrows have been considered doubtful (McAllister, 1988, 1992; Dubiel et al., 1988; Friedman and Daeschler, 2006). Other structures are undoubted lungfish burrows because they contain the articulated skull bones of the trace-maker (Romer and Olson, 1954; Carlson, 1968; Berman, 1976). Some burrows occur with the skeletons of coiled animals, others with uncoiled animals (Olson and Bolles, 1975; Hasiotis et al., 1993). Permian deposits of north-central Oklahoma have yielded interesting aestivation burrows of the lungfish Gnathorhiza (Carlson, 1968). These burrows are found in the bottom portion of silty dolomite beds and extend downward into enclosing dark brownish-red shale. Burrows mainly stand vertically and may form clumps. They are essentially cylindrical with a 
sharp narrowing toward the bottom, showing strong similarities with the studied traces. The lungfish burrows illustrated by Romer and Olson (1954, pl. 1) or Olson and Bolles (1975, on the right of pl. I, fig. C) are also very similar to the vertical shafts from Brayal. The common occurrence of burrows in clusters in the Brayal section is similar to those illustrated by Romer and Olson (1954, pl. 1). Gnathorhiza burrows, which are closely packed together with intervening distances of 10 to $70 / 80 \mathrm{~mm}$, have also been reported by Berman (1976). In conclusion, by their morphology, their filling, and their common occurrence in clusters, the studied vertical shafts show many similarities with lungfish aestivation burrows known from comparable deposits (Table 1).

\subsubsection{Amphibian aestivation burrows}

Amphibians, for example some elongate taxa of salamanders that use their head for burrowing (Wake, 1993), also commonly dig protective burrows to survive during dry seasons and are possible trace-makers. The Permian-Carboniferous freshwater deposits contain aestivation burrows of both the lungfish Gnathorhiza and the amphibian Lysorophus, and the two kinds of burrows are not so easy to differentiate (Olson and Bolles, 1975). Hembree et al. (2004, 2005) have also described interesting burrows of the lysorophid amphibian Brachydectes. These animals are elongate fully aquatic animals inhabiting ephemeral ponds on low-relief coastal plains. They burrow in response to seasonal droughts. Fossil burrows are described from the Lower Permian ephemeral ponds and are named Torridorefugium eskridgensis (Hembree et al., 2005). Two types of burrows occur. Type I burrows are elongate, elliptical tubes 200 to $300 \mathrm{~mm}$ long and 10 to 80 $\mathrm{mm}$ wide. They are vertical to oblique $\left(40^{\circ}\right)$ with respect to the bedding. Their termination is conical and rounded at the end. Type II burrows are short, elliptical tubes no longer than $50 \mathrm{~mm}$ long and 5 to $80 \mathrm{~mm}$ wide. All taper downward to a rounded, conical termination. They occur in clusters of up to 45 burrows with a maximum concentration of $20 / \mathrm{m}^{2}$. The proposed ecological 
interpretation shows that amphibians and lungfish have very similar behaviours (Hembree et al., 2005).

\subsection{Trace producers and function of structures}

The hypothesis of vertebrate aestivation burrows is not proved but seems probable. This hypothesis is supported mainly by close similarities between the most frequent burrows (vertical shafts) with well-preserved aestivation burrows of lungfish (Carroll, 1965; Carlson, 1968) and amphibians (Hembree et al., 2005). Characteristics are compared in Table 1. The resulting determination of the trace-maker remains uncertain because lungfish and amphibian burrows are rather similar and may be associated in the same environments (Olson and Bolles, 1975).

\subsubsection{Lungfish aestivation burrows (vertical burrows)}

Given the main burrow morphology (simple vertical shafts), the lungfish hypothesis is plausible. The studied specimens are very similar to the typical "cylindrical fossil lungfish burrow" proposed by McAllister (1988) corresponding to a vertical position of the lungfish. McAllister (1988) has proposed some recognition criteria that fit with the studied specimens, including: 1) occurrence in fine-grained sediment; 2) harder, more calcareous, and slightly larger-grained infill than matrix; 3) distinct sides and bottoms with indistinct tops; 4) cylindrical shape tapering slightly to a hemispherical bottom; 5) circular cross section; and main axis vertically oriented.

Because of their cylindrical shape, the shafts from Brayal could correspond to uncoiled lungfish. As suggested by Carlson (1968) for the Permian specimens, the lungfish probably used its mouth in burrowing, and then stood on its tail in the burrow during aestivation. Studied Palaeogene animals probably stood vertically within their burrows and remained head upright. The possible erosion made by their long dorsal fin could form a long vertical furrow. In the resulting trace fossil, this furrow could correspond to the ridge occurring along the shaft visible in many of our 
specimens. But this morphological feature is unknown from fossil and modern examples. A physical origin may be also possible to explain these vertical ridges. They could be secondary structures, such as fillings of desiccation cracks (Fig. 16A). Mudcracks radiating from vertical burrows have been documented (Melchor et al., 2010, fig. 4). This interpretation is consistent with the high argillaceous content of the enclosing sediment and the very shallow environment characterized by frequent sub-aerial exposure. An interpretation of the ridges as fills of desiccation cracks is unlikely, however, because these ridges are systematically isolated (only one per shaft) and they never form a characteristic polygonal network (Figs. 10, 16B).

The absence of lungfish skeletal remains inside and outside the burrows does not support the proposed hypothesis. But concerning the Permian occurrences, lungfish bones are always rare, and only four lungfish specimens were found by Berman (1976) in many hundreds of burrow casts.

It is possible that clusters including shafts, furrows and tunnels result from the burrowing activity of the same animals. Different burrow shapes occur today according to the ethology of modern lungfish. For example, both simple vertical aestivation burrows and more complex reproduction burrows with a horizontal tunnel are made by Protopterus annectens (Arambourg and Guibé, 1958). Burrowing behaviour of lungfish, and consequently the shape of the burrows, may be different between different lungfish taxa, and also between small and large specimens of the same taxon (Olson and Bolles, 1975). In conclusion, furrows and tunnels could be produced by lungfish, but other interpretations seem better for these traces, which are rather different in shape and size and are not always associated with vertical shafts.

\subsubsection{Amphibian aestivation burrows (furrow fills and tunnels)}

The main argument for this interpretation is the occurrence of well-organized scratch marks made of five identical parallel ridges (Fig. 13). They suggest the action of digits of a tetrapod animal when burrowing. This pattern, the association with possible lungfish burrows, and a larger 
size are the main arguments for the amphibian hypothesis. The burrowing behaviour of amphibians may also be highly variable and can explain the different shapes of the burrows. For example, Heatwole (1960, p. 667), on the basis of experiments with salamanders on different substrates, concluded that "presumably coiling in burrows indicates an inability to penetrate the substrate farther to reach favourable conditions". Burrows that are different in age, shape, and size have also been considered as amphibian burrows (Storm et al., 2010). All these supposed amphibian burrows are observed in environments where seasonal droughts occur.

\subsubsection{First record of lungfish in the Cainozoic of Europe?}

Lungfish first appeared in marine deposits in the Early Devonian before diversifying and occupying a wide range of ecological niches (Campbell and Barwick, 1990). The decline of lungfish starts at the beginning of the Mesozoic. From the Jurassic to the present, they have been discovered only in the Southern Hemisphere (Bertin and Arambourg, 1958). Even if remains of lungfish fossils are not common, Cainozoic remains are known only from South America, Africa, and Australia (Martin, 1982; Marshall, 1986; Kemp, 1992). The occurrence of Cainozoic specimens in France is therefore unlikely. Possible lungfish aestivation burrows, however, occur in the lowermost Cretaceous deposits of Denmark (Surlyk et al., 2008). If the studied vertical shafts are really lungfish burrows, they would represent the first documentation of Cainozoic lungfish in Europe.

\section{Palaeoenvironmental implications}

The possible occurrence of aestivation burrows in the studied deposits refines the interpretation of the palaeoenvironment. Fossil lungfish and amphibian aestivation burrows are commonly known in terrestrial environments, such as fresh-water floodplain ponds or lakes (Carlson, 1968; Olson and Bolles, 1975; Surlyk et al., 2008), where they indicate periods of sub- 
aerial exposure. On the basis of their sedimentological context, some Permian lungfish burrows were interpreted from marginal-marine environments. Concerning Gnathoriza, Schultze (1999, p. 385) thought that "the burrows may have been a protective adaptation for surviving low tide, as they are for many Recent intertidal animals". The same idea of a "protection burrow" in a lower supratidal to intertidal environment may also be relevant to the trace fossils described here.

Among the associated trace fossils in the studied sections, Thalassinoides and Psilonichnus are well known crustacean burrows. Thalassinoides occurs in relatively widespread palaeoenvironments, whereas Psilonichnus is more restricted to backshore and upper intertidal settings (Frey et al., 1984; Frey and Pemberton, 1987; Nesbitt and Campbell, 2006). Some similar modern burrows are made by thalassinidean shrimp, such as Upogebia, in sub-tidal to intertidal environments (Swinbanks and Luternauer, 1987; Gingras et al., 1999). Others are produced by the modern ghost crab Ocypode in upper intertidal to supratidal environments (Farrow, 1971; Frey and Mayou, 1971; Chakrabarti, 1981, 1993; Curran, 1994; De, 2000; Netto and Grangeiro, 2009). Ocypode, which lives in foreshore to backshore settings, is considered as a quasi-terrestrial crab (De, 2000).

Even if all these different burrows may have a relatively wide environmental range, the supposed aestivation burrows point to more terrestrial influences than Thalassinoides and Psilonichnus. Frequent cross-cutting of Psilonichnus and Thalassinoides by the supposed aestivation burrows was observed in the Brayal section. This pattern illustrates a significant change of environmental conditions. Logically, the later construction of aestivation burrows must indicate more terrestrial influences in a marginal-marine environment. Such successions of trace fossils illustrate small regressive episodes. These episodes take place in the general regressive sequence with shallow marine, followed by brackish and then lacustrine deposits, which characterize the Eocene/Oligocene transition. 
Even if the exact nature of the producers remains questionable, their environmental significance appears to be accurate. Vertical shafts are relatively common and have been observed in several sections of the studied basin. They are well exposed in the Brayal, La Bourbonne, and Barre de l'Echelette sections and near Braux. Because of the environmental significance of vertical shafts, these sections could indicate the shallowest areas of the basin, typically located close to the shoreline in a terrestrial setting. This interpretation fits with known palaeogeographical data: vertical shafts occur at the border of the late Eocene shallow marine basin of southern France and are not observed in deposits that represent deeper areas. The association of vertical shafts with furrows and tunnels has been observed only in the Brayal section. In other places (La Bourbonne, Barre de l'Echelette, Braux), only vertical shafts occur in sections where marine conditions are more obvious (more abundant marine mollusc taxa, less detrital supply). Here, these burrows could indicate shorter emersion periods in a shallow-marine environment. By comparison, the occurrence of furrows and tunnels is probably related to places that experienced longer emersions. If this is correct, the related occurrence of the probable amphibian aestivation burrows would indicate more terrestrial conditions than the occurrence of likely lungfish aestivation burrows alone. The presence of amphibians also suggests more clearly that freshwater could episodically cover the area (Fig. 17).

Continental trace fossils, and particularly aestivation burrows, have a clear relationship to palaeoclimate (Hasiotis et al., 2007). For example, the Palaeocene/Eocene Thermal Maximum (PETM) is characterized by palaeosols with crayfish burrows (Smith et al., 2008). The Eocene/Oligocene boundary also corresponds to major changes in ocean circulation and global climate (Prothero and Berggren, 1992). This boundary is situated at the transition from the greenhouse period of the Cretaceous and Early Palaeogene (uniformly warm climate) to the icehouse period of the Late Palaeogene and Neogene (more seasonal and cooler climate). This significant climatic change is characterized mainly by a global cooling and drying. For example, 
Western Europe became under a cooler and more contrasted climate (Stehlin, 1909; Collinson, 1992; Legendre and Hartenberger, 1992). As for plants, changes occurred from dominantly evergreen subtropical vegetation to a mixed evergreen and deciduous vegetation with a warm but seasonal climate in Western Europe (Collinson, 1992). As for animals, the Eocene/Oligocene boundary was called "La Grande Coupure" (the "Great Break") by Stehlin (1909), because of the dramatic changes between terrestrial biotas. For example, a major turnover occurred in mammalian faunas (Legendre and Hartenberger, 1992). A general decrease in diversity of aquatic amphibians and reptiles also occurred. This decline of aquatic taxa is related to a general increase of aridity, decrease in permanent rivers and filling of lacustrine basins (Hutchison, 1992).

If the lungfish/amphibian interpretation is correct, the occurrence of aestivation burrows of aquatic and ectothermic vertebrates has the same palaeoclimatic implications. These animals would have burrowed in response to increasing episodic droughts on the coastal plain. This could reflect the general climatic transition at the beginning of the Oligocene, including the beginning of arid conditions in south-eastern France.

\section{Conclusions}

Three different uncommon kinds of biogenic sedimentary structures are described from deposits occurring at the Eocene/Oligocene transition in south-eastern France (Castellane-Blieux area; Alpes de Haute-Provence French Department). The more frequent ones, previously named "pivots" in the literature, are vertical shafts either isolated or associated as dense clusters. Other structures are furrows and tunnels. All occur together in marginal-marine environments and crosscut crustacean burrows (Psilonichnus and Thalassinoides). 
Given the facies and morphologic similarities to modern burrows, these enigmatic trace fossils are considered as probable vertebrate aestivation burrows. The vertical shafts were probably made by lungfish owing to strong similarities with other well documented fossil burrows. Furrow fills were probably made by amphibians, mainly because of scratch marks possibly corresponding to four/five-digit imprints. Unfortunately, we found no lungfish or amphibian bones in the burrows, and our interpretation of producers must remain somewhat tentative.

Discovery of probable lungfish aestivation burrows obviously would indicate the occurrence of these animals in southern Europe in the Palaeogene. Until now, skeletal remains of lungfish of this age were only known from South America, Africa, and Australia.

The occurrence of what are likely aestivation burrows is in agreement with the palaeoenvironmental setting. These burrows are clearly located at the border of a shallow-marine basin and were formed during a well-documented emergence. Because they indicate droughts on the resulting coastal plain, they also illustrate initiation of a dryer climate that is a well-known aspect of the Eocene/Oligocene transition.

\section{Acknowledgements}

This work was supported by the CNRS (UMR 5125) "Paléoenvironnements et Paléobiosphère". We are grateful to W. Miller for constructive suggestions in improving the text. The two reviewers, Dirk Knaust and Paolo Monaco, for their constructive remarks. We are also grateful to M. Guiomar and to the European Geopark of Haute Provence for field assistance, N. Podevigne for photographic assistance and A. Prieur for collection management, and the student N. Faiche.

\section{References}


Able, K.W., Grimes, C.B., Cooper, R.A., Uzmann, J.R., 1982. Burrow construction and behavior of tilefish, Lopholatilus chamaeleonticeps, in Hudson submarine canyon. Environmental Biology of Fishes 7, 199-205.

Able, K.W., Grimes, C.B., Jones, R.S., Twichell, D.C., 1993. Temporal and spatial variation in habitat characteristics of tilefish (Lopholatilus chamaeleonticeps) off the east coast of Florida. Bulletin of Marine Science 53, 1013-1026.

Arambourg, C., Guibé, J., 1958. Sous-classe des Dipneustes (Dipneusti). In: Grassé, P.P. (Ed.), Traité de Zoologie, t. XIII, Agnathes et Poissons - anatomie, éthologie, systématique, Masson ed., fasc. 3., Masson, Paris, pp. 2523-2540.

Atkinson, R.J.A., Taylor, A.C., 1991. Burrows and burrowing behaviour of fish. In: Meadows, P.S., Meadows, A. (Eds.), The Environmental Impact of Burrowing Animals and Animal Burrows. Zoological Society of London Symposia 63. Clarendon Press, Oxford, pp. 133-155. Bedatou, E., Melchor, R.N., Bellosi, E., Genise, J.F., 2008. Crayfish burrows from Late JurassicLate Cretaceous continental deposits of Patagonia: Argentina. Their palaeoecological, palaeoclimatic and palaeobiogeographical significance. Palaeogeography, Palaeoclimatology, Palaeoecology 257, 169-184.

Berman, D.S., 1976. Occurrence of Gnathorhiza (Osteichtyes: Dipnoi) in aestivation burrows in the Lower Permian of New Mexico with description of a new species. Journal of Paleontology 50, 1034-1039.

Bertin, L., Arambourg, C., 1958. Ichthyogéographie. In: Grassé, P.P. (Ed.), Traité de Zoologie, t. XIII, Agnathes et Poissons - anatomie, éthologie, systématique, Masson ed., fasc. 3., Masson, Paris, pp. 1944-1966.

Blanc, M., d'Aubenton, F., Plessis, Y., 1956. Mission Blanc et d'Aubenton (1954), IV - Etude de l'enkystement de Protopterus annectens Owen. Bulletin de l'Institut Fondamental d'Afrique Noire 18 (3A), 843-854.

Bodelle, J., 1971. Les formations nummulitiques de l'arc de Castellane. Ph.D. Thesis, Université de Nice, France, I, 329 pp.; II, 582 pp.

Boussac, J., 1911. Etudes paléontologiques sur le Nummulitique alpin. Mémoires du Service de la Carte Géologique de France, Paris, 1-437.

Boussac, J., 1912. Etudes stratigraphiques sur le Nummulitique alpin. Mémoires du Service de la Carte Géologique de France, Paris, 1-662.

Campbell, K.S.W., Barwick, R.E., 1990. Paleozoic dipnoan phylogeny, functional complexes and evolution without parsimony. Paleobiology 16, 143-169. 
Carlson, K.J., 1968. The skull morphology and estivation burrows of the Permian lungfish, Gnathorhiza serrata. Journal of Geology 76, 641-663.

Carroll, R.L., 1965. Lungfish burrows from the Michigan Coal Basin. Science 148, 963-964.

Cavelier, C., 1984. Paléogène. In: Debrand-Passard, S., Courbouleix, S., Lienhardt, M.J. (Eds.), Synthèse Géologique du Sud-Est de la France. Mémoire du BRGM, Orléans 125, pp. 389468.

Chakrabarti, A., 1981. Burrow patterns of Ocypode ceratophthalma (Pallas) and their environmental significance. Journal of Paleontology 55, 431-441.

Chakrabarti, A., 1993. Ocypode burrows as predictors of ancient shoreline position: new findings from a barred tidal flat. Indian Journal of Geology 65, 15-24.

Colin, P.L., 1973. Burrowing behaviour of the yellowhead jawfish, Opistognathus aurifrons. Copeia 1, 85-90.

Collinson, M.E., 1992. Vegetational and floristic changes around the Eocene/Oligocene boundary in Western and central Europe. In: Prothero, D.R., Berggren, W.A. (Eds.), Eocene-Oligocene Climatic and Biotic Evolution. Princeton University Press, Princeton, pp. 437-450.

Curran, H.A., 1994. The paleobiology of ichnocoenoses in Quaternary, Bahamian-style carbonate environments: the modern to fossil transition. In: Donovan, S.K. (Ed.), The Paleobiology of Trace Fossils. John Wiley and Sons, New York, pp. 83-104.

d'Orbigny, A., 1850. Prodrome de paléontologie stratigraphique universelle des animaux mollusques et rayonnés. II., Masson, Paris, 427 pp.

De, C., 2000. Neoichnological activities of endobenthic invertebrates in downdrift coastal Ganges delta complex, India: their significance in trace fossil interpretations and paleoshoreline reconstructions. Ichnos 7, 89-113.

Dubiel, R.F., Blodgett, R.H., Bown, T.M., 1987. Lungfish burrows in the Upper Triassic Chinle and Dolores Formations, Colorado Plateau. Journal of Sedimentary Petrology 57, 512-521.

Dubiel, R.F., Blodgett, R.H., Bown, T.M., 1988. Lungfish burrows in the Upper Triassic Chinle and Dolores Formations, Colorado Plateau - Reply. Journal of Sedimentary Petrology 58, 367-369.

Farrow, G.E., 1971. Back-reef and lagoonal environments of Aldabra atoll distinguished by their crustacean burrows. Symposia of the Zoological Society of London 28, 455-500.

Frey, R.W., Mayou, T.V., 1971. Decapod burrows in Holocene barrier island beaches and washover fans, Georgia. Senckenbergiana Maritima 3, 53-77. 
Frey, R.W., Pemberton, S.G., 1987. The Psilonichnus ichnocoenose and its relationships to adjacent marine and non marine ichnocoenoses along the Georgia Coast. Bulletin of Canadian Petroleum Geology 35, 333-357.

Frey, R.W., Curran, H.A., Pemberton, S.G., 1984. Tracemaking activities of crabs and their environmental significance: the ichnogenus Psilonichnus. Journal of Paleontology 58, 333350 .

Friedman, M., Daeschler, E.B., 2006. Late Devonian (Famennian) lungfishes from the Catskill Formation of Pennsylvania, USA. Palaeontology 49, 1167-1183.

Gastaldo, R.A., Rolerson, M.W., 2008. Katbergia gen. nov., a new trace fossil from Upper Permian and Lower Triassic rocks of the Karoo basin: implications for paleoenvironmental conditions at the $\mathrm{P} / \mathrm{Tr}$ extinction event. Palaeontology 51, 215-229.

Gingras, M., Pemberton, S.G., Saunders, T., Clifton, H.E., 1999. The ichnology of Modern and Pleistocene brackish-water deposits at Willapa Bay, Washington: variability in estuarine settings. Palaios 14, 352-374.

Gitton, J.L., 1978. Apport de la paléoécologie à la reconstitution et à l'évolution d'un basin sédimentaire: l'analyse de la macrofaune des marnes bleues nummulitiques des environs de Castellane (Alpes de Haute Provence). Ph.D. Thesis, Université de Paris Sud, France, 468 pp.

Gregory, M.R., 1991. New trace fossils from the Miocene of Northland, New Zealand: Rorschachichnus amoeba and Piscichnus waitemata. Ichnos 1, 195-205.

Grimes, C.B., Able, K.W., Jones, R.S., 1986. Tilefish, Lopholatilus chamaeleonticeps, habitat, behavior and community structure in Mid-Atlantic and southern New England waters. Environmental Biology of Fishes 15, 273-292.

Hasiotis, S.T., Mitchell, C.E., 1993. A comparison of crayfish burrow morphologies: Triassic and Holocene fossil, paleo- and neo-ichnological evidence, and the identification of their burrowing signatures. Ichnos 2, 291-314.

Hasiotis, S.T., Dubiel, R.F., 1994. Ichnofossil tiering in Triassic alluvial paleosols: implications for Pangean continental rocks and paleoclimate. In: Beauchamp, B., Embry, A.F., Glass, D. (Eds.), Pangea, Global Environments and Resources. Canadian Society of Petroleum Geologists, Memoir 17, 311-317.

Hasiotis, S.T., Honey, J.G., 2000. Paleohydrologic and stratigraphic significance of crayfish burrows in continental deposits: examples from several Paleocene Laramide basins in the Rocky Mountains. Journal of Sedimentary Research 70, 127-139. 
Hasiotis, S.T., Mitchell, C.E., Dubiel, R.F., 1993. Application of morphologic burrow interpretations to discern continental burrow architects: lungfish or crayfish? Ichnos 2, 315333.

Hasiotis, S.T., Kirkland, J.I., Callison, G., 1998. Crayfish fossils and burrows from the Upper Jurassic Morrison Formation of western Colorado. Modern Geology 22, 481-491.

Hasiotis, S.T., Wellner, R.W., Martin, A.J., Demko, T.M., 2004. Vertebrate burrows from Triassic and Jurassic continental deposits of North America and Antarctica: their paleoenvironmental and paleoecological significance. Ichnos 11, 103-124.

Hasiotis, S.T., Kraus, M.J., Demko, T.M., 2007. Climatic controls on continental trace fossils. In: Miller, W. III (Ed.), Trace Fossils, Concepts, Problems, Prospects. Elsevier, Amsterdam, pp. 172-195.

Heatwole, H., 1960. Burrowing ability and behavioral responses to dessication of the salamander Plethodon cinereus. Ecology 41, 661-668.

Hembree, D.I., Martin, L.D., Hasiotis, S.T., 2004. Amphibian burrows and ephemeral ponds of the Lower Permian Speiser Shale, Kansas: evidence for seasonality in the midcontinent. Palaeogeography, Palaeoclimatology, Palaeoecology 203, 127-152.

Hembree, D.I., Hasiotis, S.T., Martin, L.D., 2005. Torridorefugium eskridgensis (new ichnogenus and ichnospecies): amphibian aestivation burrows from the Lower Permian Speiser Shale of Kansas. Journal of Paleontology 79, 583-593.

Howard, J.D., Mayou, T.V., Heard, R.W., 1977. Biogenic structures formed by rays. Journal of Sedimentary Petrology 47, 339-346.

Hutchison, J.H., 1992. Western North American reptile and amphibian record across the Eocene/Oligocene boundary and its climatic implications. In: Prothero, D.R., Berggren, W.A. (Eds.), Eocene-Oligocene Climatic and Biotic Evolution. Princeton University Press, Princeton, pp. 451-463.

Johnels, A.G., Svennson, G.S.O., 1954. On the biology of Protopterus annectens (Owen). Arkiv för Zoologi 7, 131-164.

Kemp, A., 1992. New cranial remains of neoceratodonts (Osteichthyes: Dipnoi) from the Late Oligocene to Middle Miocene of Northern Australia, with comments on generic characters for Cenozoic dipnoans. Journal of Vertebrate Paleontology 12, 284-293.

Kotake, N., 2007. Macaronichnus isp. associated with Piscichnus waitemata in the Miocene of Yonaguni-jima Island, Southwest Japan. In: Miller, W. III (Ed.), Trace Fossils, Concepts, Problems, Prospects. Elsevier, Amsterdam, pp. 492-501. 
Legendre, S., Hartenberger, J.L., 1992. Evolution of mammalian faunas in Europe during the Eocene and Oligocene. In: Prothero, D.R., Berggren, W.A. (Eds.), Eocene-Oligocene Climatic and Biotic Evolution. Princeton University Press, Princeton, pp. 516-528. Marshall, C.R., 1986. A list of fossil and extant dipnoans. Journal of Morphology, 190, Suppl. 1, $15-23$.

Martin, M., 1982. Les Dipneustes: des cousins des quadrupèdes? Les fossiles, témoins de l'évolution. Pour la Science 59, 12-23.

Martinell, J., De Gibert, J.M., Domènech, R., Ekdale, A.A., Steen, P.P., 2001. Cretaceous ray traces?: an alternative interpretation for the alleged dinosaur tracks of La Posa, Isona, NE Spain. Palaios 16, 409-416.

McAllister, J.A., 1988. Lungfish burrows in the Upper Triassic Chinle and Dolores Formations, Colorado Plateau; comments on the recognition criteria of fossil lungfish burrows Discussion. Journal of Sedimentary Petrology 58, 365-367.

McAllister, J.A., 1992. Gnatorhiza (Dipnoi): life aspects, and lungfish burrows. In: Mark-Kurik, E. (Ed.), Fossil Fishes as Living Animals. Academy of Sciences of Estonia, Institute of Geology, Tallinn, pp. 91-105.

Melchor, R.N., Genise, J.F., Farina, J.L., Sánchez, M.V., Sarzetti, L., Visconyi, G., 2010. Large striated burrows from fluvial deposits of the Neogene Vinchina Formation, La Rioja, Argentina: A crab origin suggested by neoichnology and sedimentology. Palaeogeography, Palaeoclimatology, Palaeoecology 291, 400-418.

Meulenkamp, J.E., Sissingh, W., Popov, S.V., Kovac, M., Bergerat, F., 2000. Late Rupelian. In: Dercourt, J., Gaetani, M., Vrielynck, B., Barrier, E., Biju-Duval, B, Brunet, M.F., Cadet, J.P., Crasquin, S, Săndulescu, M. (Eds.), Atlas Peri-Tethys, Palaeogeographical Maps. CCGM/CGMW, Paris, map 19.

Miller, M.F., Hasiotis, S.T., Babcock, L.E., Isbell, J.L., Collinson, J.W., 2001. Tetrapod and large burrows of uncertain origin in Triassic high paleolatitude floodplain deposits, Antarctica. Palaios 16, 218-232.

Nesbitt, E.A., Campbell, K.A., 2006. The paleoenvironmental significance of Psilonichnus. Palaios 21, 187-196.

Netto, R.G., Grangeiro, M.E., 2009. Neoichnology of the seaward side of Peixe lagoon in Mostardas, southernmost Brazil: the Psilonichnus ichnocoenosis revisited. Revista Brasileira de Paleontologia 12, 211-224.

Olson, E.C., Bolles, K., 1975. Permo-Carboniferous fresh water burrows. Fieldana Geology 33, 271-290. 
Prothero, D.R., Berggren, W.A., 1992. Eocene-Oligocene Climatic and Biotic Evolution. Princeton University Press, Princeton, 568 pp.

Romer, A.S., Olson, E.C., 1954. Aestivation in Permian lungfish. Breviora, Museum of Comparative Zoology 30, 1-8.

Schultze, H.P., 1999. The fossil record of intertidal zone. In: Horn, M.H., Martin, K.L.M., Chotkowski, M.A. (Eds.), Intertidal Fishes. Life in Two Worlds. Academic Press, San Diego, pp. 373-388.

Smith, J.J., Hasiotis, S.T., Woody, D.T., Kraus, M.J., 2008. Paleoclimatic implications of crayfishmediated prismatic structures in paleosols of the Paleogene Willwood Formation, Bighorn Basin, Wyoming, U.S.A. Journal of Sedimentary Research 78, 323-334.

Snedden, J.W., 1991. Origin and sequence stratigraphic significance of large dwelling traces in the Escondido Formation (Cretaceous, Texas, USA). Palaios 6, 541-552.

Stehlin, H.G., 1909. Remarques sur les faunules de mammifères des couches éocènes et oligocènes du Bassin de Paris. Bulletin de la Société Géologique de France 9, 488-520.

Storm, L., Needle, M.D., Smith, C.J., Fillmore, D.L., Szajna, M., Simpson, E.L., Lucas, S.G., 2010. Large vertebrate burrow from the Upper Mississipian Mauch Chunk Formation, eastern Pennsylvania, USA. Palaeogeography, Palaeoclimatology, Palaeoecology 298, 341347.

Surlyk, F., Milàn, J., Noe-Nygaard, N., 2008. Dinosaur tracks and possible lungfish aestivation burrows in a shallow coastal lake; lowermost Cretaceous, Bornholm, Denmark. Palaeogeography, Palaeoclimatology, Palaeoecology 267, 292-304.

Swinbanks, D.D., Luternauer, J.L., 1987. Burrow distribution of thalassinidean shrimp on a Fraser Delta tidal flat, British Columbia. Journal of Paleontology 61, 315-332.

Voorhies, M.R., 1975. Vertebrate burrows. In: Frey, R.W. (Ed.), The Study of Trace Fossils. Springer, Berlin, pp. 325-350.

Wake, M.H., 1993. The skull as a locomotor organ. In: Hanken, J., Hall, B.K. (Eds.), The Skull. 3: Functional and Evolutionary Mechanisms. The University of Chicago Press, Chicago, pp. 197-240.

Woodrow, D.L., Fletcher, F.W., 1969. Devonian dipnoan aestivation cylinders. Geological Society of America, Special Paper 121, 383-384.

\section{Figure captions}


Fig. 1. Palaeogeographical context during late Rupelian. Note that our work deals with a slightly older period characterized by more marine conditions in the studied area (rectangle) (modified after Meulenkamp et al., 2000, map 19).

Fig. 2. Location of the studied sections (Brayal, La Bourbonne, Barre de l'Echelette, and Braux). The dashed line indicates the supposed position of the shoreline (modified after Bodelle, 1971, fig. 207).

Fig. 3. Stratigraphic context: (A) schematic lithologic and environmental successions in the basin at the Eocene/Oligocene transition; (B) simplified geological transect from the coastal plain to the deeper marine basin for the studied interval. See Figure 2 for the location of the four sections; the orientation is more or less south (Castellane-Blieux) to north, except Annot located more to the East. The levels with the trace fossils gradually disappear towards the shallow marine basin.

Fig. 4. The Brayal section. The studied trace fossils are located mainly in the "Couches bistres" interval (beds 15 to 26), which corresponds to a transitional facies between shallow marine marls and lacustrine limestones.

Fig. 5. Top of the Brayal section showing the well exposed "Couches bistres" interval at the top of the Marnes Bleues Formation. Note the location of bed no. 15 exhibiting large enigmatic traces (arrows) and of bed no. 28 corresponding to the Calcaire Lacustre de Taulanne Formation. VS = vertical shafts; $\mathrm{n}=$ nodules. 
Fig. 6. Vertical shafts (A, C) or furrow fills $(\mathrm{B}, \mathrm{C})$ related to the bed no. 15 and crossing subjacent pedogenetic level made of very light gray calcareous nodules (also visible in Fig. 5). Brayal section, Marnes Bleues Formation, "Couches bistres". Scale $=15 \mathrm{~cm}$.

Fig. 7. La Bourbonne section. Marnes Bleues Formation. The levels displaying the trace fossils correspond to the beds no. 15 and no. 25 .

Fig. 8. Typical aspect of vertical shafts in the field. (A) La Bourbonne section, Marnes Bleues Formation; scale $=15 \mathrm{~cm}$; note the hypichnial preservation and the regular cup-shaped lamination made by the filling. (B, C) Braux section, Marnes Bleues Formation; note, in $\mathrm{C}$, the filling with bivalve fragments.

Fig. 9. Two examples of vertical shafts associated in dense clusters. (A) La Bourbonne section, Marnes Bleues Formation. (B) Brayal section, "Couches bistres". Hammer $=33 \mathrm{~cm}$ in length.

Fig. 10. Vertical shafts with longitudinal prominent ridge (arrows). (A) well preserved ridge partly broken in the lower part; La Bourbonne section, Marnes Bleues Formation. (B) broken ridge and pustular external surface; Brayal section, Marnes Bleues Formation, "Couches bistres". Scale = 15 $\mathrm{cm}$.

Fig. 11. Vertical shafts crossed by small burrows. (A) vertical shaft exhibiting a pustular relief on its external surface; general view; scale $=15 \mathrm{~cm}$. (B) detailed view of a similar specimen; the pustular relief corresponds to diagenetic features on small burrows crossing the main trace with different orientations. (C) vertical section of another specimen (FSL 187188) showing many small burrow sections (arrows). Brayal section, Marnes Bleues Formation, "Couches bistres". 
Fig. 12. Association of the three kinds of enigmatic trace fossils, Brayal section, bed no. 15, Marnes Bleues Formation, "Couches bistres". (A) field photography, on the right part of the picture, one horizontal tunnel of Thalassinoides (arrow) and visible at the bottom of the vertical shaft (vs), is cross-cut by the furrow (f). (B) schematic drawing of the same trace fossils. vs = vertical shaft; $\mathrm{f}=$ furrow; $\mathrm{t}=$ tunnel.

Fig. 13. Morphology of furrows. (A) section of the furrow FSL 157196. (B) aspect of the lower external surface of the same furrow showing several sets of parallel scratch marks suggesting the action of digits. (C) close-up view of the previous specimen having a set of 4 digits scratches.

Fig. 14. Two sections of the same tunnel showing a crossing by smaller burrows and a filling with a regular upward cup-shaped lamination. Brayal section, Marnes Bleues Formation, "Couches bistres”. FSL 157186.

Fig. 15. Crustacean burrows. (A) Part of Psilonichnus with two U-shaped morphologies (arrows) close to a vertical shaft (vs). (B) Psilonichnus with Y-shaped morphology (arrow); Barre de l'Echelette section, Marnes Bleues Formation. (C) Thalassinoides with typical Y-branching (arrow); La Bourbonne section, Marnes Bleues Formation. Scale $=15 \mathrm{~cm}$.

Fig. 16. (A) Longitudinal ridges by desiccation of the sediment enclosing the burrows (hypothesis not retained in this study). (B) Our field observations with only one longitudinal ridge occurring along a shaft, without any polygonal network indicating possible desiccation. 
Fig. 17. Possible environmental significance of the different studied trace fossils. VS = vertical shaft $; \mathrm{f}=$ furrow; $\mathrm{Ps}=$ Psilonichnus $; \mathrm{t}=$ tunnel.

Table 1. Characteristics of the vertical shafts compared to well preserved fossil aestivation burrows of lungfish and amphibians (using data from Carroll, 1965; Carlson, 1968; Hembree et al., 2005 and personal data). 